\title{
Knowledge Sources: Key Factors for an Organization in Creating New Invention and Innovation
}

Inai Dulliyah Abdullah, Saiful Farik Mat Yatin, Nurulain Khairul Anam, Nor Hafifah Hasan Adli, Sham Sul Kamal Wan Fakeh, Hanis Diyana Kamarudin, Mohd Zaihan Hussin

To Link this Article: http://dx.doi.org/10.6007/IJARBSS/v10-i11/8187 DOI:10.6007/IJARBSS/v10-i11/8187

Received: 07 September 2020, Revised: 25 September 2020, Accepted: 26 October 2020

Published Online: 22 November 2020

In-Text Citation: (Abdullah, et. al., 2020)

To Cite this Article: Abdullah, I. D., Yatin, S. F. M., Anam, N. K., Adli, N. H. H., Fakeh, S. S. K. W., Kamarudin, H. D., \& Hussin, M. Z. (2020). Knowledge Sources: Key Factors for an Organization in Creating New Invention and Innovation. International Journal of Academic Research in Business and Social Sciences. 10(11), $1127-$ 1137.

Copyright: ( 92020 The Author(s)

Published by Human Resource Management Academic Research Society (www.hrmars.com) This article is published under the Creative Commons Attribution (CC BY 4.0) license. Anyone may reproduce, distribute, translate and create derivative works of this article (for both commercial and non-commercial purposes), subject to full attribution to the original publication and authors. The full terms of this license may be seen at: http://creativecommons.org/licences/by/4.0/legalcode

Vol. 10, No. 11, 2020, Pg. 1127 - 1137

Full Terms \& Conditions of access and use can be found at http://hrmars.com/index.php/pages/detail/publication-ethics 


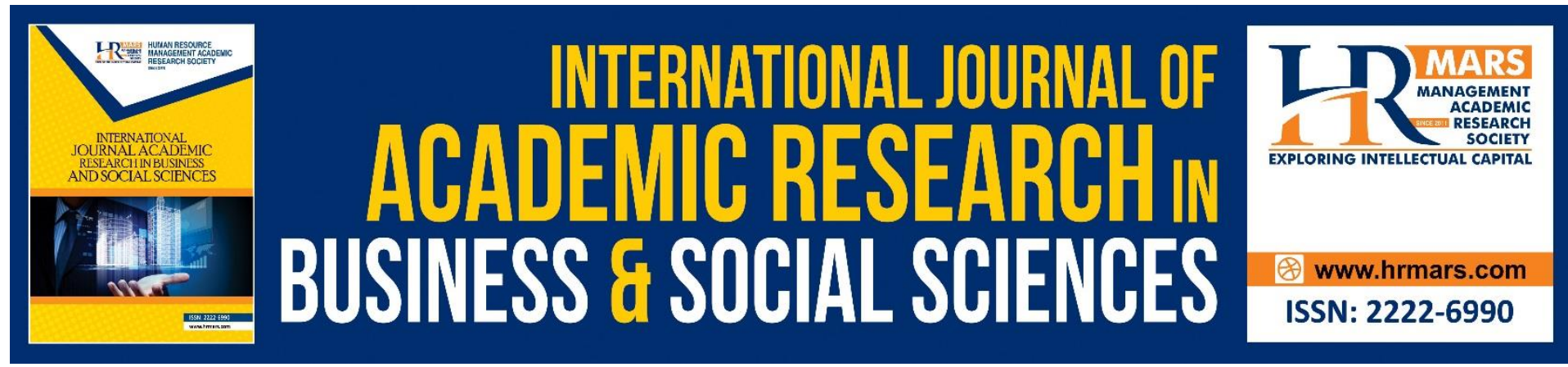

\title{
Knowledge Sources: Key Factors for an Organization in Creating New Invention and Innovation
}

\author{
${ }^{1}$ Inai Dulliyah Abdullah, ${ }^{1,2}$ Saiful Farik Mat Yatin, ${ }^{1}$ Nurulain \\ Khairul Anam, ${ }^{1}$ Nor Hafifah Hasan Adli, ${ }^{1}$ Sham Sul Kamal Wan \\ Fakeh, ${ }^{1}$ Hanis Diyana Kamarudin, ${ }^{1}$ Mohd Zaihan Hussin \\ ${ }^{1}$ Faculty of Information Management, Universiti Teknologi MARA (UiTM) Selangor, Malaysia \\ ${ }^{2}$ Members of Advanced Analytics Engineering Center (AAEC), UiTM
}

\begin{abstract}
Today's economy, in the era of Industrial Revolution (IR) 4.0, had become more challenging and globalized. However, there are ways to adapt those challenges. Many studies had determined innovation as the key for an organization pursuing growth and keep competitive in this $21^{\text {st }}$ century. Therefore, in order to remain competitive in the industry, an organization could not any longer depends solely on their tangible asset such as factories, facilities, machinery and land, instead, they need to increasingly turn their focus into their intangible asset including goodwill, brand recognition, copyrights, patents, trademarks, trade names, and customer lists, also any knowledge-based resource, information, and knowledge sources to come out with innovation. Previous studies had proved that the knowledge sources as the key factors for an organization in creating new invention, innovation, or product. Therefore, to stay on the top of the information industry or in being competitive and survive in the industry, a company, especially with the large-scale size, needs to come out with new innovation. Therefore, this paper will discuss on the how knowledge sources benefit to company innovation.
\end{abstract}

Keywords: Knowledge Management, Knowledge Sources, Knowledge Innovation, Information Industry

\section{Introduction}

In general, there are several definitions of innovation that can be referred to when conducting research related to innovation. According to Schumpeter and Opie (1983), innovation can be described as the new version of new product, process or method of production commercial or industrial application of. Abrunhosa and E Sa, (2008), stressed that since it potentially leads to productivity and competitive gains, innovation is widely acknowledged as the key to economic development. In addition, The European Commission had defined innovation as the new rebranding and extension of the products range and services and the related markets. In other hands innovation might also be described as the creation of new ways or technique of production, new methods of supply and also new ways of distribution. Besides, it can also 
determine as the early stage of transformation in management, organization, and the working environment and also skills of the worker inside the organization. (Commission of the European Communities (CEC), 1995). Bon and Mustafa (2013) stated that innovation as the adoption of idea or behaviour that is new to the organization. Therefore, innovation does not only produced by research and development ( $R$ and $D$ ), but it can be described as a multidimensional process. This process comes along with multiple sources which mostly come from much active communication among personnel, organization and also from the organizational setting. In the simplest terms, innovation can be explained as a process that involves the exploitation of new ideas in creating new product, process, or invention. Innovation is a word that may also use for referring a process, an attribute, or an end result. However, many had used the word innovation and invention. Freeman (1982) has made the interchangeably clear with this phrase: "an invention is an idea, a sketch or model for a new or improved device, product, process or system" while "an innovation in the economic sense is accomplished only with the first commercial transaction involving the new product, process, system or device."

\section{Innovation and Knowledge Sources}

Kavadas and Chao (2007) as cited by Surosa and Azis (2014) concerned on the expression "innovate or die" which has been an accepted phrase in the popular business environment. Innovation is as a process of converting ideas or invention into product or services that has an economic value. Many previous studies had proved that both ideas and invention had been the core success factor for innovation process, where it is significantly influenced by knowledge. Besides, many previous scholars especially scholars with management interest had identified innovation as an engine for growth to an organization. (Schumpeter and Opie, 1983; Volberda, Van den Bosch and Mihalache, 2014). However, innovation entails learning and adoption of new technologies and techniques. (Osoro et al., 2015).

While Aoujil (2013) cited Grant and Baden-Fuller (1995) that based to the knowledge-based perception, knowledge has been recognized as one of the key resources that can trigger innovation. Therefore, in order to stay competitive and improve their level in the industry, the firms need to adopt into many changes. They need a well-structured knowledge management system to implement and focus onto their innovation.

As denoted by Freitas et al. (2011), firms had depended so much on the varieties type of their knowledge sources in the aspect of innovation process. Those knowledge sources are much related to the application of ideas and creation which result from access to infrastructure, human capital and partners' innovative capacities. Based on a literature body that investigate the factors that influence innovation, knowledge sources has been identified as a key success factor in the new invention of organizational innovations. (Mol and Birkinshaw, 2009). Instead, McFayden and Canella (2004) suggest that knowledge may be the only or one of the most important sources of competitive advantage available to an organization in the $21^{\text {st }}$. century.

Pederson, Soo and Devinney (2002) had also stressed that there are great numbers of academical and practical studies done on identifying the connection between organizations' accomplishment and the knowledge before had showed that the higher the level of knowledge acquired or accumulated, the greater the performance level for the firm will be. 
In addition to that, Steensma and Lyles (2000) and also Stuart (2000), had determined that the resources and knowledge origins from the alliance partners is the crucial funding to the development, revolution rate (Pederson et al, 2002).

In order to enhance or retain the organization performance outcome and let the organizations accommodate, modify, expand and sustain, it is necessary for organization to do innovation. (Simao and Franco, 2018). With the innovation execution in an organization, it will trigger or allow organizational changes and facilitate the organization's renewal, adaption and effectiveness (Damanpour and Aravind, 2012).

In some previous studies (Chiang and Hung, 2010; Henttonen and Ritala, 2013; Katila and Ahuja, 2002; Laursen and Salter, 2006) had showed that there are in-depth linkage between the external knowledge and their effects on the revolution proficiency within the organizations. Laursen and Salter (2006), Chiang and Hung (2010) and Henttonen and Ritala (2013) stated that, the higher the revolution proficiency of the organizations is due to how huge and broad the influence between an organization and its knowledge references. In addition, by absorbing more knowledge, firms or company can increase their capabilities to innovate and improve their selves (Katila and Ahuja, 2002).

Furthermore, for an organization's revolution, assorted knowledge sources, for example from interior and exterior sources of the organization can be beneficial. Based on some previous studies, by using the concept of an open innovation, the existence of assorted knowledge sources will affect the total of knowledge sources that were studied (Amara and Landry, 2005; Laursen and Salter, 2006). The idea of the range and deepness of knowledge sources is to learn the total of knowledge sources. Hence, the range and deepness of knowledge sources used in the organizations. Thus the deepness of knowledge can be organized by the total of huge potency of knowledge sources used by the organizations. (Laursen and Salter, 2006).

\section{How Knowledge Sources Give Impact}

The globalization process in the industrial revolution 4.0 had made many companies starting to realize that if they want to remain competitive in the industry, they have to use the knowledge in other ways to be improved. Instead, most contemporary companies are start changing their working environment from work-based to knowledge-based company. (Alvesson, 2004).

As such, the use of knowledge as a production factor had been rise rapidly. Latest knowledge management theories had also stressed on the knowledge selling or process of incorporating it into its in intelligent products are getting increased among modern companies. These rapid changes in market had result in the increasing growth of new innovations. Besides, it also gives impact to lower product and services prices. The product life cycle also become shorter. Therefore, an organization needs to adapt with the changing market condition continuously in order to keep efficient and stay competitive in their industry (Raguz, Zekan and Peronja (n.d).

As elaborated at the beginning of this paper, the fundamental of innovation are the ideas and inventions which much greatly influenced by knowledge. Therefore, knowledge can be described as the core or root for any innovation. This including the creation, execution and 
modification of new shape of knowledge by organization in inventing their new products or services. Hence, the British Department for International Development had determined that, regarding a company innovation, two main sources of knowledge had differently gives impact to the innovation. The two sources is the internal and external sources of knowledge. (DFID, n.d.)

\section{Internal Knowledge Sources in Innovation}

Internal knowledge is one of the kind of knowledge. It is within a person based on their experience or the knowledge they gain from reading from other sources. Internal knowledge also plays an important role in enhancing the innovation of a company. According to British Department for Internal Development, (DFID, n.d), internal knowledge is best described as construction that happened in the organizations by spreading the knowledge between all members in the organizations, internal research and development (R\&D), and internal training.

Falkenberg, Woicheshyn and Karagianis (2003) also concluded that internal knowledge can be happened through internal activities amongst team members within the organizations such as research and development (R\&D) to create and replace the knowledge. Svetina and Prodan (2008) had done a study and exposed that internal sources possess leading effect towards the organization's innovation achievement. They also confirmed that, the achievements are depending on the knowledge that are built through internal research and development (R\&D), continuous enhancements, and internal training programs.

According to Fabio and Jorge (2017) in their article stated that the usage level of expenses in research and development (R\&D) should give positive effect towards innovation because it reflects the effort of the organizations. This statement is reinforced by empirical study done by (Belussi et al., 2010; Frenz and letto-Gillies, 2009; Hagedoorn and Wang, 2012; Oerlemans et al., 2013; Zaheer and Bell, 2005), research and development (R\&D) expenses gave positive impact towards organizations' innovation. This expenses and intensity are mainly represented in research and development activity (Hagedoorn and Wang, 2012).

Internal knowledge also can be obtained from team members' knowledge in their skills and experiences. These knowledges can be described through switching knowledge between team members by having conversation amongst them. This activity also can ease the organizations to achieve their innovation (Anis and Arshad, 2015).

According to Nonaka and Takeuchi (1995), there are some important elements in organizations innovation, that are learning invention, knowledge-sharing and setting up the knowledge-clustering. This statement is supported by Teece et al (1997) stated that these elements are the fundamental elements towards organizations' dynamic power.

\section{External Knowledge Sources for Innovation}

The acquisition of external knowledge includes the usage of new knowledge from sources outside a firm or organization. This acquisition might come from new machinery and equipment bought for the firm, hiring the right and qualified staff, seminars done, training, and also licensing. However, for a firm, the acquired knowledge will only be very useful if it already have existing basic knowledge which enables them to use and apply those acquired external knowledge. Instead, literaturely, scholars have different opinion regarding how far and which different knowledge sources, that greatly contribute to company' innovation performance, either internal or external knowledge (British Department for Internal Development (DFID), n.d.). In addition, Simao and Franco (2018) in their study had found out 
that the importance role of external knowledge form suppliers, clients, consultant, and commercial laboratories in new innovation practices in firm workplace is significant. However, knowledge from competitors, universities, the State and research institutes does not present any significant effect towards company innovation. Aoujil (2013) also stated that external knowledge is actually located within people that not working within the. Those people might be the clients, suppliers or person that work in other firms actively. All of those individuals actually hold several amount of knowledge that could be precious to a firm (Bierly and Daly, 2007 and Aoujil, 2013). Therefore, it is very importance for firm managers to identify which people have something that they can learn and what is the benefit of that external knowledge to the firm.

External knowledge had given varieties impacts on the technology innovation performance. This is very much depends on what the external knowledge sourcing method is used by the organization or firm. When a firm transfer information through its informal network, the firms actually has adapt the external information. Hence, the firm had gains technology innovation performance more. This shows that firms require large networks that have informality and properties of a weak tie to acquire large amount of information that come from external information sources (Granovetter, 1973; Hansen, 1999). In fact, a firm could not innovate successfully and keep survive alone in this rapid moving industry environment by just using the internal knowledge. Therefore, firms have to explore and exploit the external knowledge for innovation instead of internal knowledge alone. The firm also need to do collaboration with other organisations to keep survived and competitive in the industry. However, when firms decide to use external knowledge, it is important to them to identify how they can access the external knowledge and how far the usage of the external knowledge sourcing methods will be used for them.

In addition, Owen-Smith and Powell, (2004) had stressed that over the time, for organisational performance and innovation, the importance of external knowledge sources of has becoming deeper and in-depth. Freel, (2003) noted that no firm may function alone or on its own. Instead, resources and knowledge resources owned or controlled by other external factors is needed. This might includes customers, suppliers, competitors, stakeholders, public administration and consultants. This notion in fact has been widely accepted. Therefore, a firm can get its authority to resources and knowledge that are not located within its own firms through these external sources. Hence, this will give good impact in the financial and innovative benefit for the firm. Therefore main fact here is in creating innovations, resource deficit mechanism forces firms' innovation to change into external knowledge sources (Knoben and Oerlemans, 2010).

Therefore, in today's globalized economy, it seems hard to accept that a firm could find the right knowledge that is required for innovation only within its local environment. Moreover, when there is linkage of supply distributed all around the world and specialized knowledge and research institutions are scattered in various locations. It is supposed that firms have to look for the needed knowledge at other sources than focus only inside the firm. Besides, firm has also to continuously seek suitable innovation partners without too concerning about the geographic space (Svetina and Prodan, 2008). 


\section{The Impact of Knowledge Sources}

Knowledge sources had play important role in the aspect of creating new innovation to increase the company competitiveness. This is because knowledge sources can enable any transfer of information including specific information or sensitive information. As per said information encompasses as about the development of market research and new design of product which are to specific and sensitive to be transferred to another. (Simao and Franco, 2018). Knowledge sources also can contribute to value creation in modulization which is called modular flexibility. The organization can re-integrate the business so that the organization can focus on the quality, logic of cost, competitiveness and innovation. Modular flexibility may best be understood as the globalization of production processes, and extreme specialization of work processes with a focus on core processes (Gershuny and Fisher, 2014). According to Rigby and Zook (2002) and Aoujil, (2013), when going through the innovation process, the process of innovation can't be depending on only internal sourcing, but the process also need the knowledge from outside their knowledge understanding. In the research, "open-market" have been mentioned in the research which is strengthen on the advantage of raise the process of innovation into flows of external knowledge. The research also shows that the integration of internal and external knowledge sources is crucial as competitive advantages sources to extend the business to grow faster and bring the profit to companies.

Knowledge sources gives a part of ideas and invention creation and both internal and external sources are significantly influenced by the action of the human to react to the respective circumstances. Knowledge is thus a necessary for innovation and the creation of ideas and in some organization, the term we called New product Development (NPD) is go through by knowledge sources process. Internal and external sources are the main sources of knowledge that can impact the innovation differently. Internal knowledge can be noticed in the inside of the organizations which can be received by meeting with team and the internal training conducted by the organizations. External knowledge can be noticed from outside sources such as purchase of machinery and attending the conference. External knowledge will be benefit for the organizations if the organizations owned the base of the knowledge that allows it to use the external knowledge. Apart from that, we can conclude that the external sources are bring more ideas creation to the organization however the cost of using it is bigger than internal sources which bring to the SME's or small capital company to implement the external sources as ideas creation. According to Torben Pedersen and Christine Soo, management literature has put as knowledge sources as sources of competitive advantage and have been supported widely (i.e., Winter, 1987; Quinn, 1992; Nonaka and Takeuchi, 1995). Both internal and external sources are contributed to the competitiveness advantages of the company. By right, the combination issues which are the importance of internal and external sourcing in the organizations allow them to deal with the main component of competitive advantages is located in the unique firm specific attributes. Competitive advantage is the circumstances where the company have benefit more than to his competitors to cater and attract the customers or suppliers to have a connection with the respective company. To make it short, the invention of new ideas and the competitive advantages of the company is coming from the existence of internal and external knowledge.

Current era is more toward the globalization and technology which is production has taken a paradigm shift to the transfer the economy and production in the market using the information and knowledge which is called 'knowledge-based' economy. As we already know, 
in the present time, knowledge have become a necessary for economic resource. Consequence, many of organization or company whether small or big, they are realized that the potential of Knowledge Management, thus the ability to know the difference between internal and external sources within the organization or company is strengthen among the employees and person in the management. More likely, the internal and external sources is lead to the needy of the Information Technology (IT) and the present of technologies in current times have allowed some ideas for plentiful circumstances of opportunities. The companies and organizations can collect, analyze and share the information as well as knowledge easily and effectively with enjoying the high speed of internet connection. The usability of IT and the existence of knowledge management systems can reduce the time barriers and dissemination of knowledge faster than usual which can adapt with the dynamic market changes.

The innovative ventures can come not only from the academic person and user innovators but as well as to the employees to come or generate the ideas to come with the greater result and outcome. In Addition, innovation is part of identifying factors that impact an ability of the firm to get profit in an organization or company. On the other hand, Cooperation can be easier to the organization with the advent of the network connection and electric commerce which has been used globally and widely. (Mudge,1999). Most of the organizations are likely to use network and electronic commerce to be having a connection between them by electronic commerce. Previously, the organizations only can meet among them with face to face interaction which is difficult for them who have a far distance to meet. However, with the technology of network connection, the organization can meet among them anywhere and anytime through cyberspace.

The fragmented knowledge which are called internal and external knowledge can be combined via the inappropriate use of knowledge and the technologies in term of communication. Means, organizations can use and integrate the knowledge by using technologies. Thus, the difficulties to communication that happen between the different department of an organization can be reduced accordingly. At the same time, the industries can insert some amount of money as their capital for technological infrastructure such as cyber physical system, big data and artificial intelligent as most of the companies are toward to industrial revolution 4.0. Industrial revolution can support the different types of language and knowledge and monitor the connection in difficult situation.

Core in the knowledge acquisition process is the process that involve the use of existing knowledge in an excellent method and the exquisite the new knowledge effectively (Inkpen and Dinur, 1998). The practices must be identified so that we can choose the best option and differentiate which practice bring a more benefit to the companies or organizations. The creation of the new knowledge is relied on the connection between employees in the organizations. We can conclude that that, more the employees having connection between others, more the knowledge sharing that he/she possess. The knowledge not only limited to other's knowledge but extend to the people experience.

\section{Conclusion}

From the study done, we can conclude that, knowledge sources are absolutely play important role in the process of innovation done by an organization in creating innovation, thus to increase their competitiveness and survival in the industry. As knowledge sources is an intangible asset for a company, knowledge sources should be managed wisely by the managers by using the best knowledge management system they can afford. In order to keep 
competitive and more efficient their business, an organization has to adapt the changing market condition continuously. However, to accomplish this goal, all company's knowledge resources is necessary to be mobilized. Accessibility and availability of the capital is becoming available and accessible information, and no longer becomes the main concern of the top management. Exploiting and creating new knowledge will create a new value achieved. Hence, the intellectual property had become the company's most valuable asset.

\section{Acknowledgement}

This article is financially supported by:

1. Faculty of Information Management, UiTM Selangor, Malaysia

2. Advanced Analytics Engineering Center (AAEC), UiTM Malaysia

\section{Rereferences}

Abrunhosa, A., \& E Sá, Patrícia Moura (2008). Are TQM principles supporting innovation in Portuguese footwear industry? Technovation, 28(4) 208 - 221. https://doi.org/10.1016/j.technovation.2007.08.001

Alvesson, M. (2004). Knowledge work and knowledge-intensive firms. Oxford: Oxford University Press (OUP).

Amara, N., \& Landry, R. (2005). Sources of information as determinants of novelty of innovation in manufacturing firms: Evidence from the 1999 statistics Canada innovation survey. Technovation, 25, 245-259.

Anis, K., and Arshad, J. (2015). Sourcing Knowledge for Innovation: Knowledge Reuse and Creation in Project Terms. Journal of Knowledge Management. Vol. 19 Issue: 5, pp.932-948. URL: https://doi.org/10.1108/JKM-01-2015-0039.

Anne, K. (2011). Firm-Internal Knowledge Integration and The Effects on Innovation. Journal of Knowledge Management, Vol. 15 Issue: 6, pp.984-996. URL: https://doi.org/10.1108/13673271111179325.

Aoujil, M. (2013). External knowledge in the innovation process. (Unpublished Master Thesis). Tilburg University, Netherlands.

Barney, J. (1991). Firm resources and sustained competitive advantage. Journal of Management, 17(1), 99-120.

Bon, A. T., \& Mustafa, E. M. A. (2013). Impact of total quality management on innovation in service organizations: literature review and new conceptual framework, Procedia Engineering, 53, 516-529.

Bierly, P. E., \& Daly, P. S. (2007). Alternative knowledge strategies, competitive environment, and organizational performance in small manufacturing firms. Entrepreneurship Theory and Practice,31(4), 493-516. doi:10.1111/j.1540-6520.2007.00185.x

Birkinshan, J., \& Fey, C. F. (2001). External Sources of Knowledge and Performance in R and D Organisation. Journal of Management, 31(4), 597-621.

British Department for International Development (DFID), (n.d.). Effect of knowledge sources on firm level innovation policy brief. Retrieved from https://assets.publishing.service.gov.uk/media/ 5aab839c40f0b66b5fb4bc7c/2bf5d304-21e2-4b94-a8e7-1652d1fcb0aa_Policy_brief

Commission of the European Communities (CEC). (1995), Community on Green Paper on Innovation (COM), (95) 688

Copenhagen, T., Soo, C. (2002). The Importance of Internal and External Knowledge Sourcing and Firm Performance: A Latent Class Estimation 
Chiang, Y., \& Hung, K. (2010). Exploring open search strategies and perceived innovation performance from the perspective of inter-organizational knowledge flows. Rand $D$ Management, 40(3), 292-299.

Damanpour, F., \& Aravind, D. (2012). Managerial innovation: Conceptions, processes, and antecedent. Management and Organization Review, 8 (2), 423-454.

Falkenberg, L. E., Woicheshyn, J., \& Karagianis, J. (2003, June). Knowledge sourcing: Internal or external. Paper presented at the $5^{\text {th }}$ International Conference of Organizational Learning and Knowledge, Lancaster University. Retrieved from https://warwick.ac.uk/fac/soc/wbs/conf/olkc/archive/olk5/papers/paper16.pdf

Freel, M. S. (2003). Sectoral patterns of small firm innovation, networking and proximity. Research Policy, Vol. 32, No. 5, pp.751-770.

Freeman, C. (1982). The Economics of Industrial Innovation. $2^{\text {nd }}$. ed. London: Francis Pinter.

Freitas, I. M., Clausen, T. H., Fontana, R., \& Verspagen, B. (2011). Formal and informal external linkages and firms' innovative strategies: A cross-country comparison. Journal of Evolutionary Economics, 21(1), 91-119

Granovetter, M. (1973). The strength of weak ties. American Journal of Sociology, 78, 13601380

Grant, R. M., \& Baden-Fuller, C. (1995). A knowledge-based theory of inter-firm collaboration. Academy of Management Journal: Best Papers Proceedings. 17-21.

Hansen, M. T. (1999). The search-transfer problem: The role of weak ties in sharing knowledge across organisation subunits. Administrative Science Quarterly, 44(1), 82-111.

Henttonen, K., \& Ritala, P. (2013). Search far and deep: Focus of open search strategy as driver of firm's innovation performance. International Journal of Innovation Management, 17(3), 1340007-1 s.d. 1340007-20.

Inkpen, A. C., \& Dinur, A. (1998). Knowledge Management Processes and International Joint Ventures. Organization Science, 9(4), 454-468.

Katila, R., and Ahuja, G. (2002). Something old, something new: A longitudinal study of search behaviour and new product introduction. Academy of Management Journal, 45(6), 1183-1194.

Kavadas, S., \& Chao, R. O. (2007). Resources Allocation and New Product Development Portfolio Management, in Handbook of New Product Development Research. Oxport: Elsevier/Butterworth

Knoben, J., and Oerlemans, L. A. G. (2010). The importance of external knowledge sources for the newness of innovations of South African firms'. Int. J. Innovation and Regional Development, Vol. 2, No. 3, pp.165-181.

Laursen, K., \& Salter, A. (2006). Open for innovation: The role of openness in explaining innovation performance among U.K. manufacturing firms. Strategic Management Journal, 27, 131-150.

Mol, M. J., \& Birkinshaw, J. (2009). The sources of management innovation: when firms introduce new management practices. Journal of Business Research. 62(12), 12691280.

Nonaka, I., \& Takeuchi, H. (1995). The Knowledge-Creating Company. New York: Oxford University Press.

OECD. (2005). The measurement of scientific and technological activities: Oslo manual: Guidelines for collecting and interpreting innovation data, $3^{\text {rd }}$. ed., Paris: OECD EUROSTAT 
Osoro, O., Kahyarara, G., Knoben, J., \& Vermeulen, P. (2015). Effect of knowledge sources on firm level innovation in Tanzania. DFID working paper.

Owen-Smith, J., \& Powell, W. W. (2004). Knowledge networks as channels and conduits: the effects of spill overs in the Boston biotechnology community. Organization Science, Vol. 15, No. 1, pp.5-21.

Pacharapha, T., and Ractham, V. V. (2012) Knowledge acquisition: the roles of perceived value of knowledge content and source, Journal of Knowledge Management, Vol. 16 Issue: 5, pp.724-739, https://doi.org/10.1108/13673271211262772

Pederson, T., Soo, C., \& Devinney, T. M. (2002). The importance of internal and external knowledge sourcing in firm performance: A latent class estimation.

Raguz, I. V., Zekan, S. B., \& Peronja, I. (n.d.). Knowledge as a source of competitive advantage in knowledge-based companies.

Simao, L., \& Franco, M. (2018). External knowledge sources as antecedents of organizational innovation in firm workplaces: a knowledge-based perspective. Journal of Knowledge Management, 22(2), 237-256. Retrieved from https://doi.org/10.1108/JKM-01-20170002

Schumpeter, J. A., \& Opie, R. (1983). The theory of economic development: An inquiry into profits, capital, credit, interest, and the business cycle. New Brunswick, N.J.: Transaction Book.

Stuart, T. E. (2000). Interorganizational alliances and the performance of firms: A study of growth and innovation rates in a high technology industry. Strategic Management Journal, 21, 791-811.

Steensma, H. K., \& Lyles, M. A. (2000). Explaining IJV survival in a transitional economy through social exchange and knowledge-based perspectives. Strategic Management Journal, 21(8), 831- 851.

Suroso, E., \& Azis, Y. (2014). Defining mainstreams of innovation: A literature review. Paper presented at $1^{\text {st }}$ International Conference on Economics and Banking (ICEB-15). Retrieved from: https://www.atlantispress.com/php/download_paper.php?id=25405

Svetina, A. C., \& Prodan, I. (2008). How internal and external sources of knowledge contribute to firms' innovation performance. Managing Global Transition, 6(3), 277-299.

Volberda, H. W., Van den Bosch, F. A., \& Mihalache, O. R. (2014). Advancing management innovation: Synthesizing processes, levels of analysis, and change agents. Organization Studies, 35(9), 1245-1264.

Zandi, G., Rabbi, F. (2015). The Impact of Knowledge Management, Infrastructure and Process on University Performance. SEGi Review, Vol.9, 107-119. URL: https://www.segi.edu.my/onlinereview/pdf/vol8-no2-art9.pdf. 